\title{
Comparative Study on the USER Experience of the Glocalpressurjc Website in Different University-based Cultural Contexts
}

\author{
Sonia Valle deFrutos \\ University Rey Juan Carlos, Madrid, Spain
}

\begin{abstract}
This research paper sets out to present the comparative results on the use of the Glocalpressurjc website by university students from two different cultural contexts and professional levels, by means of journalistic practices. By preparing questionnaires we shall quantitatively evaluate the students' perception of the website, the concept of quality journalism and, in particular, quality education in general.
\end{abstract}

Keywords: quality journalism, international journalism, slow journalism, cyberculture, glocalpressurjc, educational innovation, constructivism.

\section{Context of the Research}

The continuous introduction of Information and Communication Technology (ICT) at Faculties of Communication Sciences involves a relentless drive towards offering quality teaching. As a result, universities set out to facilitate the development of professional skills (know-how) in line with the new professional profiles of journalists by fostering ICT (UNIVERSITIC, 2015).

The Libro Blanco de los Títulos del Grado en Comunicación en España (White Paper on University Degrees in Communication Studies in Spain) (ANECA, 2005, p. 204) highlights certain skills which should have been achieved by students pursuing these degrees upon graduation, which include the skill and capability of communicating in the language of each of the traditional media (press, photography, radio, television), in their modern combined forms (multimedia) or on new digital media (the Internet), by means of hypertextuality. It also underlines the skill and capability of using information and communication technologies and techniques in different media or combined and interactive media systems (multimedia), as well as the skill of using computer systems and resources and their interactive applications. And finally, it mentions the skill and capability of designing formal and aesthetic aspects of digital, audiovisual, graphic and print media, as well as using computer techniques to depict and transmit facts and data through infographic systems.

In the learning process for multimedia journalism, we adopt the constructivist paradigm (Hernández, 2008) as a way of building knowledge through context-based activities; a digital culture where autonomous learning, collaborative learning through the use of digital tools and innovation all play a key role. This involves the student being immersed in a practical environment in which they can develop personally while enjoying the most professional conditions possible.

Sonia Valle deFrutos, Vice-dean, Faculty of Communication Sciences, University Rey Juan Carlos. 
In this context and to allow journalism students to develop in the most professional manner possible, the website Glocalpressurjc arose five years ago as a result of the educational innovation project "Writing in the Classroom" (Valle de Frutos et al., 2012, 2015). Since then it has been used for the practical part of the Multimedia Journalism subject on different degree courses, such as the honours degree in Journalism, the joint honours degrees in Journalism and Law, Journalism and Economics, Journalism and History, and Journalism and Political Science, and the honours degree (semi-distance) in Journalism offered by the Faculty of Communication Sciences at the University Rey Juan Carlos.

The primary goal of the project is to simulate an online multimedia newsroom in which students are involved with different roles, ranging from writers to editors, while rotating around the different sections that make up each of the publications of the newspaper. The workflow is based on organising the class into as many teams as sections covered by the publication. The teams meet to propose and discuss the content that should be developed during practical teaching sessions in the laboratory.

Since its creation, the Glocalpressurjc platform has presented a simple and intuitive interface, the design of which was first based on a barely-modified free-of-charge Drupal content manager template known as "Acquia Marina”, with Trebuchet MS and Verdana fonts. Later, there were changes in the design when we started using the Starboard template with a view to creating a more professional website with the features described below.

On the one hand, the three columns on the homepage of the website are now managed separately. The left column is used to identify users. The middle column shows the content with a photo, a headline and an intro, which in turn is selected and ranked by the teaching team. The right column shows featured content from each of the three publications. The platform is enabled for each publication, in turn, to rank the content under the criteria of quality, timeliness, relevance and interest.

The platform has eight different publications, seven of which focus on primarily local information from Alcalá, Alcorcón, Coslada, Fuenlabrada, Leganés, Móstoles and Vicálvaro (see Figure 1). Four of these towns are home to Universidad Rey Juan Carlos Campuses, while the rest are surrounding municipalities, and include sections on International News, National News, Madrid News, Local News, Health, Culture, Sports, Gender and Communication.

The eighth publication, known as "World", features international news with content created by students on the semi-distance degree in Journalism. The sections that tend to form part of "World" are International Society, Europe, World Crisis, Spain in the World, International Cooperation, Protest, Cultures, Communication, Arab Uprisings and University.

Ecuadorian students browsing the site suggested the use of "World" and the importance of adapting to the local context to increase the quality of posts. This took into account the importance of gaining quality work experience in journalism on a regional level. To this end, the names of five of the ten sections were changed so they could reflect Ecuadorian diversity and also the students' home country and possible media coverage. As a result, names of Ecuadorian towns were used for the sections, with Europe being renamed Ambato; World Crisis changing to Cuenca; International Cooperation becoming Riobamba; the Culture section taking on the name Latacunga; and Arab Uprisings being called Salinas de Guaranda (see Figure 2). 


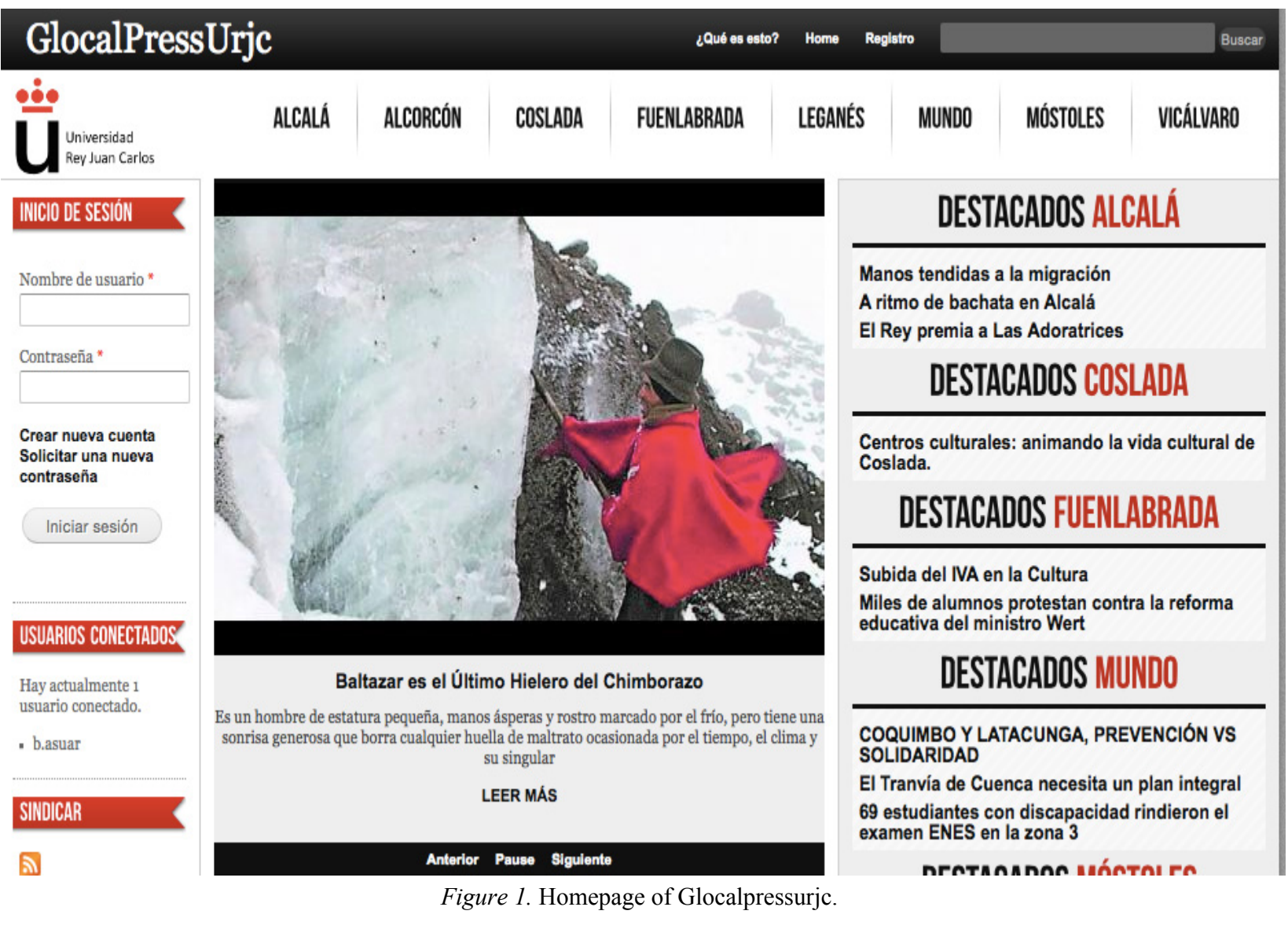

\section{SECCIONES}

Sociedad Internacional
Ambato
Cuenca
España en el Mundo
Riobamba
Indignados
Latacunga
Comunicación
Salinas de Guaranda
Universidad

Figure 2. Sections of the "World" publication on Glocalpressurjc after being adapted to local coverage in Ecuador.

In this context, and in parallel, we addressed the attributes that are closest to "quality journalism" in order to measure or observe the students' perceptions of the Glocalpressurjc platform based on their experience and use of the website during their practical experience. To do this, we referred to the study by Lacy and Rosenstiel (2015, p. 27), which — in brief - highlights presentation quality or accessibility of the news to a diverse public; trustworthiness as a way of giving thoroughness and credibility to content; diversity when it comes to sources, ideas and content; depth and openness of content; comprehensiveness, in that the content covers a wide range of trends; and geographical relevance. 
Diversity in storytellingor in the use of different ways of presenting information, either narrative, non-narrative or as multimedia, with the use of links and other sources, is an important way of increasing the quality of journalistic content. However, it is also important to highlight the use of slow journalism as a way to apply certain Internet genres that we use during classes in order to present content with the greatest depth and reflection possible. We are referring to argumentative Internet genres, such as editorials or video analysis; and to interpretive Internet genres, such as news reporting and multimedia. We also take the concept of glocaljournalism into account so as to include different geographical areas in terms of coverage, from local to global, especially in the "World" section.

Meanwhile, the quality journalism index is considered as another way of measuring quality upon evaluating the following elements that refer to the process of creating journalistic content and social contribution (Lacy \& Rosenstiel, 2015, p. 34): (1) Selection process ("a quote from the source of the information, the nature of the sources, the factual aspect of the matter, degree of topicality and newsworthiness); (2) Preparation process ("accuracy, depth, presence of different perspectives within the item, contribution made by other information elements, and correctness of journalistic language); and (3) Social contribution ("power watchdog, promotion of social debate, respect for human dignity, presence of cultural references from other countries, and the combating of social marginalisation").

\section{Methodology}

For this research paper, which sets out to provide a comparative analysis of the experience of using the Glocalpressurjc website in two different cultural contexts, namely Spanish and Ecuadorian, a questionnaire with twenty questions was drafted. Most of the questions were common to both groups, while some were specially developed to reflect the Ecuadorian context. The study sample was similar from the quantitative point of view and data was collected in the same calendar year, 2015, although in different academic terms. There were 23 students in the Spanish group and 25 in the Ecuadorian group.

Meanwhile, although in the Ecuadorian group the students were studying a Master in Digital Journalism ${ }^{1}$ and in the Spanish group the students were final-year undergraduates ${ }^{2}$, the profile was similar in bothcases. The students were mostly professionals, in the sense that they have worked or will be working in the media, especially in the Ecuadorian case.

What is more, the average age was similar, i.e., greater than the normal age of students carrying out undergraduate studies.

The journalistic work approach was also very similar. Both groups worked on the publication of "World", taking it in turn to create journalistic content in different formats. First of all, argumentative content or Internet genres were created, from the editorial to the opinion column. Then they would work on multimedia interviews and reporting as a dialogical Internet genre and later on the interpretative approach, creating headline and second-tier reports and articles, as well as articles to be tweeted. And finally they would write online news articles following the recommendations of readability and usability suggested by recent studies in the area. Meanwhile, use was made of other tools available to the platform, such as comment moderation to encourage interactivity among users, an essential process that guarantees reflection in the form of a forum or debating group through comments on the different articles published.

\footnotetext{
1 Master in Digital Journalism at the Universidad Técnica de Ambato, Ambato, Ecuador.

${ }^{2}$ Blended Degree in Journalism at the Universidad Rey Juan Carlos, Madrid, Spain.
} 
The first preliminary hypothesis was to assume that the Ecuadorian group would give a less positive evaluation than the Spanish group, taking into account the fact that their level of knowledge was in theory higher, as they were studying a Master. However, it turned out to be the opposite. The explanation behind this may be that with a higher level of knowledge, it is easier to appreciate the functionality and features that the platform provides for practising digital and multimedia journalism.

The questionnaire used to evaluate the website and its quality as a platform for conducting journalistic practices consisted of twenty questions with answers based on the Likert scale. The scale had five items: strongly agree, agree, neither agree nor disagree, disagree and strongly disagree. For the Ecuadorian group there were three different questions. One related the use of the newspaper as a way of fostering collaboration between universities, and another to the relationship between adapting the "World" publication to the Ecuadorian context and the quality of journalistic content created. And the third extra question referred to the use of Twitter in the production of creative journalistic content. Finally, students were asked an open-ended question (to complement the closed nature of the questionnaire) about the concept of quality journalism and quality education.

For the Spanish group, one of the three questions referred to the coverage of different campuses or locations of the university, while the second asked how the "World" publication was an adequate option considering that is used by the semi-distance group studying the Multimedia Journalism subject. Meanwhile, the third question asked whether the inclusion of personal blogs on the platform was necessary.

The students were offered the opportunity to use keywords to express what they understood by quality journalism and quality education, meaning that the study was complementary to the closed questions. Despite language differences, in that the sample groups were Spanish speakers but the form of expression could vary as one group lived in Ecuador and one in Spain, we were able to observe that certain words are synonymous and have the same meaning yet in different cultural contexts. In fact, one of the luxuries of the Glocalpressurjc project was the diversity in the language used when content was being created. It was important to use a standard Spanish as the target audience or user were in both Spain and Ecuador.

\section{Research Results}

As for the overall comparative results with regard to the questionnaire, based on statements in which there was no negative evaluation of the website, $42.8 \%$ of the Ecuadorian students on the Master agreed, versus $46.9 \%$ of the Spanish students on the semi-distance degree. $50.4 \%$ of Ecuadorians students strongly agreed with the statements compared to $25.2 \%$ of the Spaniards. In contrast, the Spanish undergraduate students were more critical, with $4.7 \%$ disagreeing and $2.8 \%$ strongly disagreeing, compared to $0 \%$ of the Ecuadorian Master students. Meanwhile, $6.8 \%$ of latter said they neither agreed nor disagreed, compared to $4.78 \%$ from the semi-distance degree group.

It is very significant that the question which received the highest evaluation from the two groups was the same one, i.e., the training of multimedia journalists with regard to the possibility of using multimedia resources on the website. $56 \%$ of the Spanish students and $72 \%$ of the Ecuadorian students strongly agreed with this statement.

As for the group of Master students, it is interesting to highlight the three questions with which they strongly agreed. The first referred to the importance of organising multimedia writers into teams each with an editor. The second considered how the use of the Glocalpressurjc newspaper allows us to develop transferable 
skills, such as teamwork and learning to learn. The third question on which there was also full agreement stated that the platform could become a professional digital newspaper. The group of undergraduate students also fully coincided with the latter. This suggests that both groups have a clear perception of the high potential that the website could have as a professional newspaper.

However, it is worth noting some suggestions given by the Ecuadorian students which should be taken into account when upgrading the platform. On the one hand, they said that the design could be improved by making it more attractive and user-friendly, i.e., a less formal layout with more eye-catching headlines, thereby suitable for a more general audience. Comments were also made on the possibility of improving font styles, creating new categories, adding menus and incorporating more widgets.

In terms of content, suggestions were made to expand and rethink local content with links that would provide contact to the journalists involved in the newspaper. They also mentioned the importance of enhancing the treatment of photos by using a high-definition photo gallery showing local news, as well as the use of short videos with precise information.

As for the level of interaction and updates, the importance of consistency in content production, with a constant immediacy, was underlined. In this regard, it is important to highlight the need for a permanent team that can feed the platform with news and also streamline the dynamics of groups creating the sections.

As for the issue related to educational innovation, the students were asked a question in which they had to compare the practices developed on the platform with those done in other subjects and then decide whether Glocalpressurjc is an educational innovation tool by comparison. The result was similar in both groups; in the case of the Master students $88 \%$ were in favour, while $82.6 \%$ of the undergraduates thought the same. The result was satisfactory as in it positively reflected the application of one of the objectives for the website, i.e., to experience educational innovation in one of the core subjects of the degree in Journalism, namely, Multimedia Journalism.

Along the same lines, the Ecuadorian group was asked about the use of social media and its relationship in helping produce creative content, such as the example of tweeted articles. The group's opinion was very favourable, with $68 \%$ strongly agreeing, $24 \%$ agreeing and only $1 \%$ neither agreeing nor disagreeing, while no students disagreed or strongly disagreed.

With regard to the evaluation of the development of collaborative learning, two questions were created. One refers to the possibility of autonomous learning, with the results being very favourable in both groups ( $92 \%$ of the Master students and $86.9 \%$ of the undergraduate students). In the other question which challenged the ability to enhance active student participation with the use of Glocalpressurjc, the results were also higher in the Master group (96\%) than in the undergraduate group (60.8\%). In the latter case, the difference was greater than in the previous one.

As for quality journalism, a crucial question considering that it is one of the main objectives of the website, the Master group was in full agreement. The results showed that $44 \%$ strongly agreed and $36 \%$ agreed, with $20 \%$ neither agreeing nor disagreeing, and not one single student disagreeing or strongly disagreeing.

In the case of the undergraduate group, $60.8 \%$ of the students agreed that the website facilitated quality journalism, while $30 \%$ had no clear answer, in other words neither agreeing nor disagreeing, and there was only one student who did not agree with the premise.

Given that quality journalism is a concept that can be studied from different approaches and measured from various aspects, it has several meanings, mainly due to the complexity underlying the term "quality", so 
another quantitative and open-ended question was asked in parallel, using keywords or attributes that refer to this concept. The Ecuadorian Master group primarily related quality journalism to immediacy, while the Spanish group related it to truthfulness (see Figure 3). However, verification, in second place, was named by $20 \%$ of the Ecuadorian group, so we can also state that it holds a good position.

Looking at these attributes, we can observe that the Master group identifies more with those covered by the study than those identified by the undergraduate group.

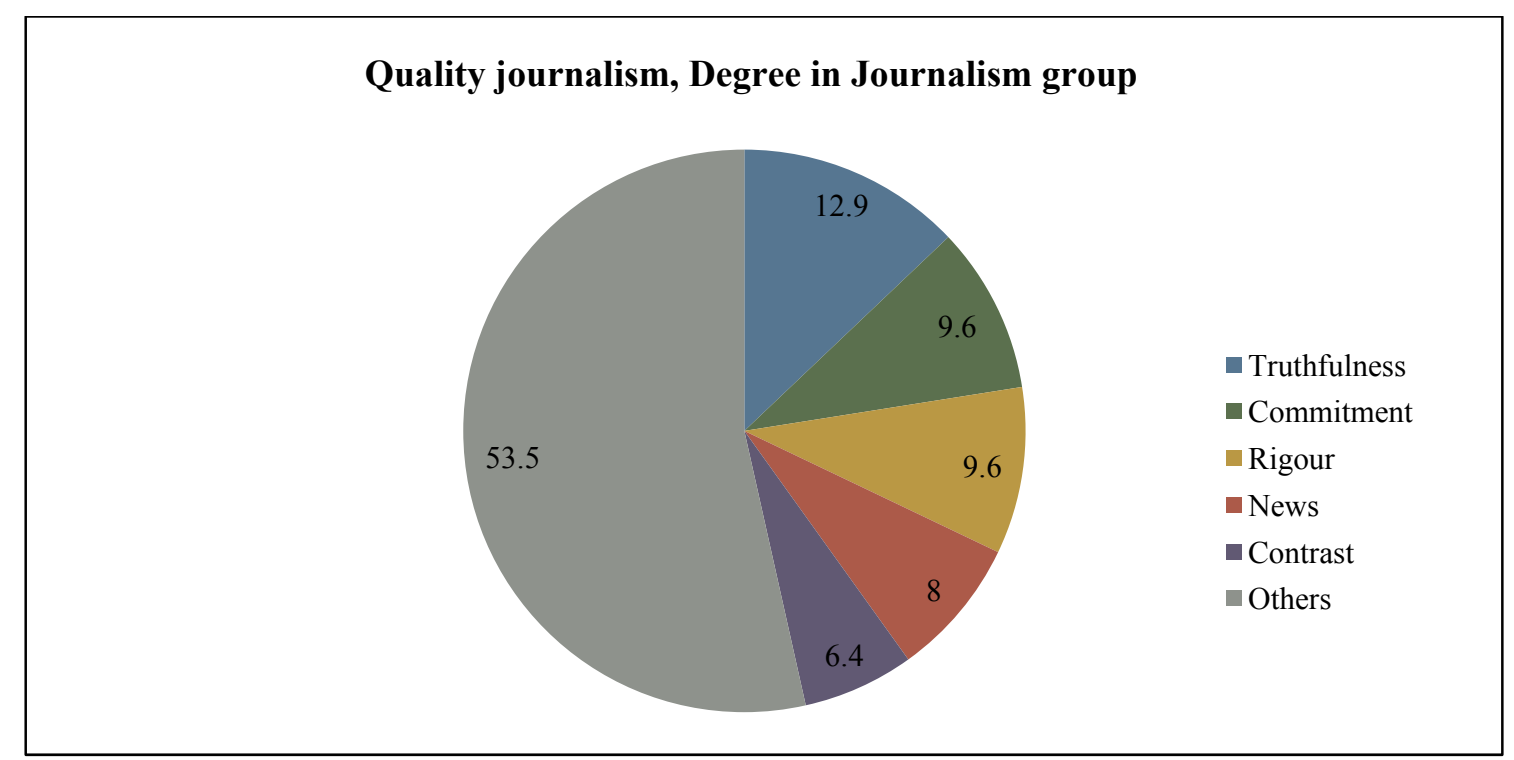

Figure 3. Internal source. Keywords regarding "quality journalism”. Results of Master in Journalism group and Degree in Journalism group.

Another question that also referred to quality, but in relation to education, asked whether a project such as Glocalpressurjc increased quality in education, in overall terms. Almost $70 \%$ of students on the semi-distance Degree in Journalism said they were in favour of this idea, compared to almost $90 \%$ of students on the Master in Journalism. On the other hand, $12 \%$ of the latter group said they neither agreed nor disagreed, compared with $30 \%$ of the undergraduate group.

The comments from students in the Ecuadorian Master group were flattering, with three particularly standing out. The first referred to one of the project objectives, in which students are able to carry out work experience as similar as possible to that found in a professional environment, with the respondent stating that "the Glocalpressurjc platform is very useful for trying out the real-life model of a digital multimedia newspaper, which is really enriching for the Master module". Another statement worthy of highlighting mentions quality as an important factor in the use of the newspaper: "The Glocalpressurjc newspaper project encourages the education of quality journalism with regard to creating content from the local context for the global context". And finally, the statement of an indigenous student explaining that "it is a very important platform on which native populations can make our cultural wealth known and also learn about the wealth that exists in Ecuador. I hope the platform keeps on working as always and that nothing changes. I also hope they continue with the same professionalism and transparency". 

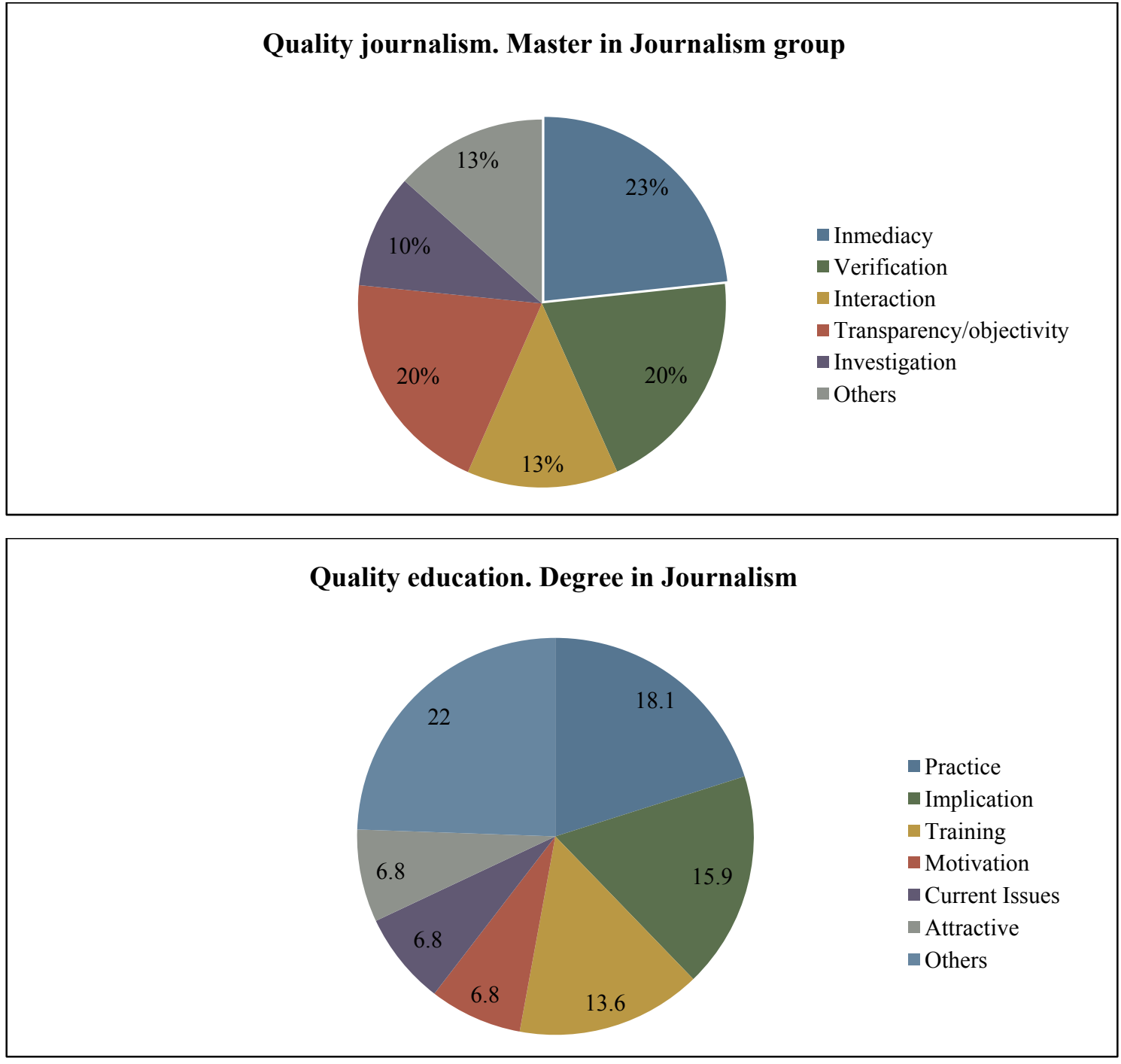

\section{Quality education. Master in Journalism}

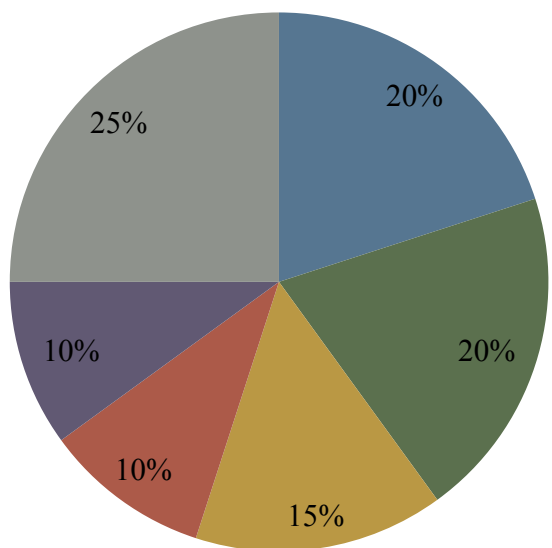

Knowledge

- Aplication

- Professional

- Responsability

- Innovation

- Others

Figure 4. Internal source. Keywords regarding "quality education". Results of Degree in Journalism group and Master in Digital Journalism group. 


\section{Concluding Remarks}

The possibility of offering students a platform with enough features to undertake work experience in a situation as close as possible to a multimedia newsroom is one of the objectives that must remain in Faculties of Communication. Not such an easy challenge given the rapidly evolving innovations in terms of journalistic tools.

According to the development of Glocalpressurjc and the responses of students who have worked with this educational innovation platform, the following conclusions can be drawn. First of all, the Glocalpressurjc teaching innovation project, after five years of existence, has been endorsed by the students. This clearly shows that the initiative has been well received by students from a different cultural context. It also broadens the scope of education through practical activities linked to quality journalism.

The first preliminary hypothesis was to assume that the Ecuadorian group would give a less positive evaluation than the Spanish group, taking into account the fact that their level of knowledge was in theory higher, as they were studying a Master. However, it turned out to be the opposite. The explanation behind this may be that with a higher level of knowledge, it is easier to appreciate the functionality and features that the platform provides for practising digital and multimedia journalism.

The way that Glocalpressurjc operates with different publications, sections and different groups in each one, with an editor who rotates every week and the development of slow journalism Internet genres that add audiovisual and hypertext elements, is a practice that fosters the coverage of real journalism.

The use of the "World" publication adapted to different cultural contexts has facilitated media coverage of a higher quality. The development of local coverage in the case of the Ecuadorian students has helped apply the constructivist learning model based on activities where context plays an important role. The simple and specialised use of the Glocalpressurjc newspaper has enabled students to gain knowledge applied to publishing journalistic pieces and news routines according to the cultural context of each group.

Glocalpressurjc helps develop transferable skills such as teamwork and learning to learn by practising journalism on a multimedia platform. The project improves the quality of education and student motivation with active participation that also fosters autonomous student learning thanks to the favourable use of the students' local and cultural context. Therefore, the Glocalpressurjc platform, after enhancing the design and restructuring the various campus publications and the "World" publication, could aspire to be the digital newspaper of the University. The user experience of the platform by the Ecuadorian students has triggered a cultural and professional exchange, which is undoubtedly worth sharing as an example of journalistic enrichment.

\section{References}

ANECA. (2005). Libro Blanco. Títulos de Grado en Comunicación. Agencia Nacional de Evaluación de la Calidad y Acreditación (White Paper on University Degrees in communication studies in Spain). Retrieved from http://www.aneca.es/var/media/150336/libroblan-co_comunicacion_def.pdf

Cabrera, M. A. (2010). La interactividad de las audiencias en entornos de convergencia digital (The interactivity of the audience in environments of digital convergence). Re-vista Icono, (Icono Review), 14(15), 164-177.

Del la Piscina, T. R., Gorosarri, M. G., Aiestaran, A., Zabalondo, B., \& Agirre, A. (2014). Quality journalism in times of crisis: An analysis of the evolution of European reference press (2001-2012). Revista Latina de Comunicación Social (Latin Review of Social Communication), 69, 248-274.

Fernández, J. G., \& Valle de Frutos, S. (2015). Glocalpressurjc, un periódico desde la innovación y calidad (Glocalpressurjc, a newspaper from innovation and quality viewpoint). XII Foro Internacional sobre Evaluación de la Calidad de la Investigación y la Educación Superior (The XII International Forumon Evaluation of the Quality of Research and the Degree Education) (FECIES), Sevilla, Fecha. 
Flores, J. M., \& Martínez, F. (2011). Las Tecnologías de la Información y de la Comunicación: Con-textualización e innovación docente para los nuevos perfiles profesionales de Periodismo (Information and Communication Technologies: Contextualización and educational innovation for the new professional profiles of Journalism). Retrieved from http://www.revistalatinacs.org/11SLCS/actas_2011_IIICILCS/191.pdf

García de Madariaga Miranda, J. M., Valle de Frutos, S., Gomes Franco e Silva, F., \& Fernández Romero, D. (2013). GlocalPressUrjc: una propuesta innovadora para la docencia en periodismo (GlocalPressUrjc: An innovative offer for the teaching in journalism). XIV Congreso de Periodismo Digital (XIV Congress of Digital Journalism).

Hernández Requena, S. (2008). El modelo constructivista con las nuevas tecnologías: aplica-do en el proceso de aprendizaje (The model constructivista with the new technologies: Applied in the learning process). Retrieved from http://www.uoc.edu/rusc/5/2/dt/esp/hernandez.pdf

Lacy, S., \& Rosenstiel, T. (2015). Defining and measuring quality journalism. Retrieved from http://mpii.rutgers.edu/wp-content/uploads/sites/129/2015/04/Defining-and-Measuring-Quality-Journalism.pdf

López, X., Calvo, M. D., \& Otero, M. (2009). El espacio universitario: Bolonia y la formación del ciberperiodista (The university space: Bologna and the formation of the cyberjournalist). In F. SABES, \& J. J. VERON (Eds.), Retos del periodismo digital: Reflexiones desde la universidad (Digital journalism challenges: Reflections from the university) (pp. 164-176). Zaragoza: Association of the Press of Aragon.

Martí, D. (2008). Blogs educativos de comunicación en Iberoamérica (Educational blogs of communication in Latin America). Retrieved from http://www.dialogosfelafacs.net/76/articulos/pdf/76DanielMarti.pdf

Masip, P., \& Palomo, B. (2010). Efectos de la tecnología en la profesión y en la producción periodística (Effects of the technology in the profession and in the journalistic production). In M. A. Cabrera (Ed.), Evolución tecnológica y cibermedios (Technological evolution and cybermedia) (pp. 55-75). Social communication, Publishing and Company, Zamora.

McLuhan, M., \& Nevitt, B. (1972). Take today: The executive as dropout. Nueva York: Harcourt Brace Jovanovish.

O'Reilly, T., \& Battelle, J. (2005). What is Web 2.0? Design patterns and business models for the Next Generation of Software. Retrieved from http://oreilly.com/web2/archive/what-is-web-20.html

Parra Valcarce, D. (2009). El uso de los blogs entre los profesores de periodismo en España (The use of blogs by journalism's teachers in Spain). Retrieved from http://www.icono14.net

UNIVERSITIC. (2015). Analisis de las TIC en las universidades españolas (TIC analyses in the Spanish universities). Retrieved from http://www.crue.org/Documentos\%20compartidos/Publicaciones/Universitic/UNIVERSI-TIC_2015.pdf

Valle de Frutos, S. (2011). Cibercultura y civilización universal: Hacia un nuevo orden cultural (Cyberculture and universal civilization: Leaning towards a new cultural order) (2nd ed.). Barcelona: Erasmus ediciones.

Valle de Frutos, S. (2016). Revisión de los procesos de cibertransculturación en medios de comunicación minoritarios en red (Review of cibertransculturation processes in minority mass media on the Internet). Retrieved from http://www.ae-ic.org/ponencias/ho- me.asp

Valle de Frutos, S., \& Fernández, J. G. (2015). Glocalpressurjc, un periódico para la innovación educativa (Glocalpressurjc, a newspaper for educational innovation). Proceedings from International Conference on Integrated Journalism Education Research and Innovation, Barcelona, Fecha.

Valle de Frutos, S., García de Madariaga Miranda, J. M., Gomes Franco e Silva, F., \& Fernández Romero, D. (2012). Redacción Digital en el Aula (Digital writing in the Classroom). Congreso: III Congreso Internacional Comunicación 3.0: Las media enterprises y las industrias culturales, investigar en comunicación y los nuevos medios (Congress: III International Communication Congress 3.0: Media enterprises and the cultural industries, to investigate in communication and the new media).

Vehkoo, J. (2015). What is quality journalism and how it can be saved?. Retrieved from https://reutersinstitute.politics.ox.ac.uk/sites/default/files/What\%20is\%20Quality\%20Journalism\%20and\%20how\%20can\%2 0it\%20be\%20saved'.pdf 